\title{
PENERAPAN STRATEGI PREDICT, DISCUSS, EXPLAIN, OBSERVE, DISCUSS, EXPLAIN (PDEODE) PADA PEMBELAJARAN IPA SD UNTUK MENINGKATKAN PEMAHAMAN KONSEP DAN MENURUNKAN KUANTITAS SISWA YANG MISKONSEPSI PADA MATERI PERUBAHAN WUJUD BENDA DI KELAS V
}

Oleh:

Suci Zakiah Dewi ${ }^{1}$, Andi Suhandi ${ }^{2}$

Universitas Pendidikan Indonesia

\begin{abstract}
Understanding of concepts in science learning is very important in order to avoid students misconceptions and is one of the requirements for success in learning science. the purpose of this study was to determine the extent of students' understanding of the concept and the ability to decrease the quantity of misconceptions by using learning strategies PDEODE at primary school level precisely in one of the Government Elementary School in the city of Bandung. The method used is quasi-experimental with pretest-posttest control group design. The process of learning happens in the classroom control with traditional learning in the classroom and experiment with strategies PDEODE. Learning takes place during the four meetings of each class and in each of the activities carried out are also observations about the enforceability of the learning activities as described in the steps in the lesson plan. The results showed an increased understanding of the concept as well as a decrease in the quantity of students' misconceptions after learning implemented. T test results showed that between $t_{\text {tabel }}$ predetermined with the calculation results tcount discovered show that $t_{\text {hitung }}$ $t_{\text {hitung }}<t_{\text {tabel }}$ and means $H_{o}$ rejected. Furthermore, students' responses to the use PDEODE strategy is positive. Students feel more involved in the learning process and thus deemed not to saturate a given learning can improve understanding of concepts and reconstruct his conception so in accordance with the scientific concept indeed.
\end{abstract}

Keyword: PDEODE Strategy, Conceptual Understanding, Misconception

\begin{abstract}
Abstrak: Pemahaman konsep dalam pembelajaran sains merupakan hal yang sangat penting guna menghindari miskonsepsi pada siswa dan merupakan salah satu syarat dalam mencapai keberhasilan belajar sains. tujuan dari penelitian ini adalah untuk mengetahui sejauh mana kemampuan pemahaman konsep siswa dan penurunan kuantitas miskonsepsi dengan mengunakan strategi pembelajaran PDEODE di jenjang sekolah dasar tepatnya di salah satu Madrasah Ibtidaiyah di kota Bandung. Metode penelitian yang digunakan adalah kuasi eksperimen dengan control group pretestpostest design. Proses pembelajaran terjadi di kelas kontrol dengan pembelajaran tradisional dan di kelas eksperimen dengan strategi PDEODE. Pembelajaran berlangsung selama 4 kali pertemuan masing-masing kelas dan dalam setiap kegiatannya dilakukan juga observasi mengenai keterlaksanaan kegiatan pembelajaran seperti tertera dalam langkah-langkah di RPP. Hasil penelitian menunjukkan adanya peningkatan pemahaman konsep serta penurunan kuantitas siswa miskonsepsi setelah pembelajaran dilaksanakan. Hasil uji t menunjukkan bahwa antara $t_{\text {tabel }}$ yang telah ditentukan dengan hasil penghitungan $t_{\text {hitung }}$ yang ditemukan menunjukkan bahwa $t_{\text {hitung }}<t_{\text {tabel }}$ dan artinya $H_{o}$ ditolak. Selanjutnya tanggapan siswa terhadap penggunaan strategi PDEODE adalah positif. Siswa merasa lebih terlibat dalam proses pembelajaran dan dianggap tidak membuat jenuh sehingga pembelajaran yang diberikan mampu meningkatkan pemahaman konsep dan merekontruksi konsepsinya sehingga sesuai dengan konsep ilmiah sesungguhnya.
\end{abstract}

Kata kunci: Strategi PDEODE, pemahaman konsep, miskonsepsi, perubahan wujud benda

\section{PENDAHULUAN}

IPA dikenal sebagai sains yang berasal dari bahasa Latin "scientia" yang berarti pengetahuan. Pengetahuan yang diperoleh melalui pembelajaran dan pembuktian. Dalam bahasa Inggris sains

\footnotetext{
${ }^{1}$ Mahasiswa Sekolah Pascasarjana UPI Bandung, Email: suci.zakiah@yahoo.com

${ }^{2}$ Dosen Universitas Pendidikan Indonesia
} 
dikenal juga sebagai Natural Science atau Science. Natural berarti alamiah atau segala hal yang memiliki sangkut paut dengan alam dan Science berarti ilmu pengetahuan. Jadi secara harfiah IPA merupakan ilmu pengetahuan yang membahas tentang alam semesta. Carin \& Sund (1989) mendefinisikan sains adalah suatu sistem untuk memahami alam semesta melalui observasi dan eksperimen yang terkontrol. Selain itu Carin \& Sund juga memberikan petunjuk tentang bagaimana seharusnya IPA diajarkan yaitu dengan menanamkan rasa ingin tahu dalam diri siswa tentang alam sekitar dan memahami penjelasan-penjelasan ilmiah tentang fenomena alam.

Dalam pembahasan mengenai hakikat IPA, Hardy dan Fleer (1996) membahas bahwa sains dapat dipahami dalam perspektif yang lebih luas lagi, hakikat yang terkandung didalamnya diantaranya adalah: (1) Sains sebagai kumpulan pengetahuan (body of knowledge), sains sebagai kumpulan pengetahuan mengacu pada kumpulan berbagai konsep sains yang sangat luas. (2) Sains sebagai suatu proses penelusuran umunnya merupakan suatu pandangan yang menghubungkan gambaran sains yang berkaitan erat dengan kegiatan laboratorium beserta perangkatnya. (3) Sains sebagai kumpulan nilai. Hal ini berhubungan erat dengan penekanan sains sebagai proses, bagaimanapun juga pandangan ini menekankan pada aspek nilai ilmiah yang melekat dalam sains dan termasuk didalamnya nilai kejujuran, rasa ingin tahu, dan keterbukaan akan berbagai fenomena yang barusekalipun. (4) Sains sebagai suatu cara untuk mengenal dunia karena proses sains dipengaruhi oleh cara di mana orang memahami kehidupan dan dunia di sekitarnya, sains dipertimbangkan sebagai suatu cara dimana manusia mengerti dan memberi makna pada dunia di sekeliling mereka.

Berdasarkan temuan di lapangan hasil penelitian Sigit \& Nurmala (2013) terdapat banyak miskonsepsi yang dialami siswa dalam memahami konsep IPA dengan benar, konsep-konsep yang menjadi tema utama penelitian diantaranya adalah : (1) Konsep udara menghasilkan tekanan ke segala arah, jawaban benar siswa dalam konsep ini masih rendah dengan rata-rata persentase dari jawaban benar hanya 27,95\%. Pertanyaan yang diajukan adalah "Dapatkah balon mengembang (bila ditiup), apabila balon tersebut diikat pada mulut botol?" Kebanyakan siswa menjawab balon tersebut dapat mengembang mengikuti bentuk botol yang lonjong. (2) Konsep pengembunan, miskonsepsi siswa cukup rawan karena jawaban benar hanya 24,8\%, dengan pertanyaan apa yang terjadi jika es disimpan di dalam gelas kaca? apa alasannya? Jawaban siswa diantaranya air keluar dari gelas melalui pori-pori gelas dan karena siswa pernah melihat bahwa es mengluarkan asap maka dari situasi tersebut diturunkan suatu teori bahwa es menguap.

Selain itu, penelitian lainnya dilakukan oleh Clara, dkk tahun 2013 mengenai miskonsepsi yang terjadi pada siswa SD materi sifat dan perubahan wujud benda di kelas III dan IV SDN 47 Sekadau Pontianak menunjukkan bahwa siswa masih memiliki konsepsi yang keliru (miskonsepsi). Konsep mengenai sifat-sifat benda cair dan contohnya, siswa kelas III yang miskonsepsi sebanyak $78,57 \%$ dan kelas IV sebanyak $80 \%$, konsep sifat-sifat benda gas dan contohnya, siswa kelas III yang miskonsepsi sebanyak $71,43 \%$ dan kelas IV sebanyak $73,33 \%$, konsep perubahan yang terjadi pada benda akibat pemanasan hanya dilaksanakan di kelas III dan siswa yang miskonsepsi sebanyak 57,14\%. Sementara konsep perubahan wujud dan contohnya hanya dilaksanakan di kelas IV, siswa yang miskonsepsi sebanyak 73,33\%. Data diperoleh dari keseluruhan 
sampel yakni 14 siswa kelas III dan 15 siswa kelas IV.

Penyebab miskonsepsi bisa saja dari faktor guru, seperti dalam penelitian yang dilakukan oleh Kambouri tahun 2012 bahwa penyebab miskonsepsi yang terjadi pada anak-anak melibatkan guru sebagai salah satu penyebabnya. Dalam kegiatan wawancara dengan beberapa narasumber (guru) di 150 sekolah di Cyprus menunjukkan bahwa sebanyak $72 \%$ setuju bahwa keyakinan guru dalam mengajar bisa menjadi salah satu penyebab tidak fokus dalam memberikan materi kepada siswa, ketidakyakinan tersebut berarti berkurangnya kepercayaan diri karena materi yang akan diajarkan belum terlalu dikuasai oleh guru. Guru lebih percaya diri mengajarkan materi tanaman dan hewan dibandingkan materi listrik maka hasilnya banyak murid yang miskonsepsi dalam materi tersebut karena disadari oleh guru mereka tidak terlalu percaya diri dalam mengajarkannya sehingga banyak sekali konsep-konsep yang kurang dipahami oleh siswa. Selain dari faktor guru, beberapa hal lain yang mempengaruhi miskonsepsi adalah kurangnya waktu untuk belajar yang disediakan kurikulum dengan kapasitas kemampuan siswa dalam menerima materi pelajaran serta tidak sesuainya pengetahuan yang diberikan guru dengan buku-buku pelajaran yang digunakan. Buku-buku yang digunakan tersebut tidak memperhatikan aspek-aspek yang dapat menimbulkan miskonsepsi dalam diri siswa, sehingga sebaliknya ketika seorang guru sudah memahami dan menguasai betul materi yang akan diajarkan namun kenyataannya konsep yang ada dalam buku pelajaran menjadi awal munculnya miskonsepsi.

Pembelajaran inkuiri dapat membantu siswa belajar lebih ilmiah terampil mengumpulkan fakta, menyusun konsep, menyusun generalisasi secara mandiri. Kemudian pembelajaran kooperatif juga membangun kemampuan kerja sama siswa dalam hal mencari fakta secara bersama-sama, faham konstruktivisme dijadikan landasan karena mengandung unsur bahwa seseorang membina pengetahuan dirinya secara aktif dengan cara membandingkan informasi baru dengan pemahaman yang sudah ada. Pentingnya kolaborasi dari ketiga hal ini adalah agar dapat memfasilitasi terjadinya konstruksi pengetahuan melalui proses asimilasi dan akomodasi dengan strategi yang dipilih adalah strategi PDEODE (Predict, Discuss, Explain, Observe, Discuss, Explain). Strategi PDEODE awalnya digunakan oleh Kolari, dkk tahun 2005 dalam pendidikan teknik. Strategi mengajar ini merupakan strategi yang mendukung suasana diskusi dengan latar belakang perbedaan pendapat.

Salah satu strategi pembelajaran yang digunakan dalam dunia pendidikan khususnya pembelajaran IPA adalah strategi PDEODE. Sebelum strategi PDEODE ini sebenarnya ada strategi lain yang hampir sama dengan strategi ini yaitu strategi POE (Predict, Discuss, Observe). Menurut Palmer tahun 1996 strategi ini dapat digunakan untuk mengetahui prakonsepsi peserta didik, memberikan informasi tentang pemikiran peserta didik, dan memotivasi peserta didik untuk menggali konsep. Namun, langkah pembelajarannya hanya terdiri dari 3 kegiatan saja yaitu memprediksi, diskusi dan observasi saja sehingga dirasa kurang kompleks untuk mengatasi permasalahan belajar dalam hal remediasi miskonsepsi sains di MI/SD.

Strategi PDEODE memiliki enam tahapan, yaitu tahap prediction, tahap discuss, tahap explain, tahap observe, tahap discuss, tahap explain (Costu, 2008).

1. Tahap memprediksi (Prediction). Pada tahap ini guru mengenalkan suatu fenomena yang berkaitan dengan materi yang akan dibahas dan yang ada dalam kehidupan sehari-hari 
sehingga berlaku dan dialami oleh semua siswa. Awalnya siswa diminta secara individu untuk memprediksi masalah dan alasannya berdasarkan pengetahuan awal mereka.

2. Tahap diskusi I (Discuss I). Siswa dibagi ke dalam beberapa kelompok, dan mendiskusikan pendapat masingmasing untuk menghasilkan jalan keluar dari permasalahan yang dihadapi. Diharapkan juga siswa mampu membuat hipotesis awal berdasarkan buku sumber yang terkait dengan fenomena yang diberikan guru.

3. Tahap menjelaskan I (Explain I). Tahap ini lebih mengarah kepada penjelasan antar kelompok, siswa diminta menjelaskan prediksinya berdasarkan pendapat masing-masing kelompok sehingga memungkinkan timbulnya konflik kognitif. Pemikiran awal siswa dapat bertentangan dengan konsep ilmiah sehingga dari sinilah dapat muncul miskonsepsi. Miskonsepsi yang ada dapat membedakan hasil diskusi antar kelompok.

4. Tahap Observasi (Observe). Perbedaan pendapat yang terjadi tidak dibiarkan berlarut-larut dan selanjutnya perlu dilakukan tindakan melalui kegiatan observasi langsung. Observasi dilakukan dengan percobaan-percobaan yang berkaitan dengan fenomena tersebut, dari kegiatan ini akan diperoleh kebenaran mengenai hipotesis yang diramalkan serta pendapat siswa dan membenahi miskonsepsi yang terjadi.

5. Tahap diskusi II (Discuss II). Kegiatan diskusi yang kedua ini untuk merumuskan kembali dan membandingkan antara hipotesis awal sebelum percobaan dengan kenyataan yang diperoleh setelah dilakukan percobaan. Dalam tahap ini siswa belajar membenahi apa yang dianggap benar tapi ternyata salah konsep menjadi sesuatu yang benar dan sesuai dengan konsep ilmiah yang sudah diuji kebenarannya.

6. Tahap menjelaskan II (Explain II). Tahap ini siswa selesai mengkonstruk pengetahuan lama dan pengetahuan barunya kemudian menjelaskan kembali sesuai dengan kesepakatan baru yang telah di diskusikan sebelumnya dalam kelompok masingmasing.

Pertimbangan dalam memilih strategi PDEODE sejalan dengan pendapat Wulandari (2013) yang mengemukakan bahwa dengan strategi PDEODE siswa terlatih untuk memprediksi, berdiskusi, menjelaskan, mengobservasi, mendiskusikan hasil observasi, kemudian menjelaskan kembali, dengan kegiatan yang berulang melatih mahasiswa semakin terasah dalam keterampilan berpikir kritis. Dalam strategi PDEODE ini terdapat pembelajaran bermakna yang mengabungkan beberapa strategi diantaranya strategi belajar kolaboratif, strategi student centered yang mengutamakan aktivitas siswa, kegiatan observasi langsung dengan melakukan percobaan-percobaan, dan strategi pemecahan masalah. Penelitian ini dilaksanakan di kelas V di salah satu MI di kota Bandung, yang sebelumnya telah diadakan penelitian secara informal mengenai pemahaman siswa dalam pembelajaran sains pada materi perubahan wujud benda yang dimiliki oleh siswa. Dari 30 siswa rata-rata hanya $10 \%$ siswa yang mampu menjawab setiap pertanyaan untuk menguji kemampuan pemahaman konsep.

Miskonsepsi siswa, langkah-langkah strategi PDEODE serta penelitianpenelitian yang dianggap relevan mengenai miskonsepsi dengan rencana penelitian ini mendorong penulis untuk melakukan penelitian lebih jauh lagi mengenai penerapan strategi PDEODE dalam upaya mengurangi kuantitas miskonsepsi siswa khususnya pada materi 
wujud benda di kelas V MI. Upaya tersebut dituangkan dalam bentuk penelitian kuantitatif dengan rumusan permasalahan "Bagaimana pengaruh penerapan strategi PDEODE dalam meningkatkan pemahaman konsep dan menurunkan kuantitas siswa yang miskonsepsi pada materi perubahan wujud benda di kelas 5 MI?". Lebih khusus lagi rumusan masalah dituangkan dalam pertanyaan penelitian sebagai berikut: (1) Bagaimana peningkatan pemahaman konsep siswa MI yang mendapatkan pembelajaran IPA dengan strategi PDEODE dibandingkan siswa yang mendapatkan pembelajaran IPA dengan pembelajaran tradisional pada materi perubahan wujud benda ? (2) Bagaimana penurunan kuantitas siswa miskonsepsi yang mendapatkan pembelajaran IPA dengan strategi PDEODE dibandingkan siswa yang mendapatkan pembelajaran IPA dengan pembelajaran tradisional pada materi perubahan wujud benda ?

\section{METODOLOGI PENELITIAN}

Penelitian ini menggunakan metode eksperimen dengan jenis penelitian eksperimen semu (Quasi Experimental Research) karena tidak mungkin dapat mengontrol semua variabel yang relevan. Variabel bebas dalam penelitian ini adalah strategi pembelajaran yang digunakan, untuk kelas eksperimen pembelajaran PDEODE dan untuk kelas kontrol pembelajaran tradisional. Variabel terikat dalam penelitian ini adalah pemahaman konsep dan penurunan kuantitas miskonsepsi siswa. Sedangkan variabel terikat dalam penelitian ini adalah kondisi kelas yang sama, alokasi waktu belajar yang sama, usia siswa yang relative sama, instrument yang diberikan untuk penilaian yang sama pula. Desain yang digunakan adalah control group pre-test - post-test design. Sebelum dilaksanakan penelitian maka dilakukan pengukuran dulu di awal disebut pre-test ini dilakukan sebelum diberikan treatment kepada siswa di kelas kontrol dan kelas eksperimen. kemudian siswa diberikan treatment (pada kelas eksperimen), dan terakhir diberikan tes akhir (post-test) terhadap kedua jenis kelas dengan soal yang sama juga.

Prosedur penelitian yang dilaksanakan yaitu (1) Melakukan kajiaan pustaka mengenai strategi PDEODE, pemahaman konsep, miskonsepsi dan materi-materi pelajaran IPA di MI khususnya kelas V. (2) Melakukan observasi awal di sekolah yang menjadi target penelitian berupa pengamatan langsung mengenai proses pembelajaran di kelas dan wawancara dengan guru, kemudian melakukan tes untuk memperoleh gambaran mengenai pemahaman konsep dan miskonsepsi siswa. (3) Merancang perangkat pembelajaran berdasarkan silabus kemudian dibuat dalam bentuk Rencana Pelaksanaan Pembelajaran (RPP), kegiatan pembelajaran dan LKS untuk kelas eksperimen dan kelas kontrol. (4) Menyusun instrumen penelitian berupa tes pilihan ganda untuk mengukur pemahaman konsep siswa dan three tier test untuk mengukur kuantitas miskonsepsi. (5) Melakukan validasi instrumen tes (judgment). (6) Mengolah data hasil uji coba yang meliputi tingkat kesukaran, reliabilitas dan daya pembeda, kemudian menganalisisnya dan menentukan soal yang akan digunakan dalam penelitian. (7) Memberikan pre-test pada kelas eksperimen dan kelas kontrol. (8) Memberikan perlakuan (treatment) pembelajaran IPA dengan strategi PDEODE pada kelas eksperimen dan dengan pembelajaran tradisional pada kelas kontrol. (9) Memberikan post-test untuk mengetahui pemahaman konsep dan kuantitas miskonsepsi setelah mendapatkan treatment. (10) Memberikan tes skala sikap pada siswa untuk mengetahui tanggapan siswa mengenai pelaksanaan pembelajaran dengan strategi PDEODE (11)Mengolah data hasil post- 
test, tes skala sikap dan hasil observasi dari seluruh pembelajaran yang dilakukan pada kedua kelompok sampel. (11) Menganalisis data hasil penelitian dan membahas temuan penelitian, memberikan kesimpulan berdasarkan hasil pengolahan data dan memberikan rekomendasi berdasarkan hasil penelitian.

Instrumen tes diberikan untuk mengukur pemahaman konsep dan miskonsepsi. Soal untuk mengukur pemahaman konsep adalah pillihan ganda biasa dan hasil tes pemahaman konsep akan dihitung gain dinormalisasi (N-gain) dan digunakan untuk melihat pemahaman konsep pada kelas kontrol dan kelas eksperimen. Soal untuk tes konsepsi siswa meskipun berupa soal pilihan ganda namun menggunakan TTT yaitu diberikan soal pilihan ganda pada tingkat pertama, kemudian tingkat kedua siswa harus menyertakan alasan menjawab opsi pertama dan tingkat ketiga siswa harus memberikan keyakinan dalam menjawab jawaban sebelumnya yakni terdiri dari yakin dan tidak yakin. Sedangkan TTT digunakan untuk mengidentifikasi adanya miskonsepsi, konsepsinya sudah benar, kurang paham konsep, menebak atau tidak tahu konsep.

Instrumen non tes yang digunakan adalah lembar observasi dan tes skala sikap siswa. lembar observasi merupakan daftar isian yang diisi oleh observer untuk mengamati secara langsung kegiatan pembelajaran di kelas dengan tujuan untuk mengetahui apakah aktivitas guru dan siswa sesuai dengan batasan-batasan yang telah digariskan dalam tahapan langkahlangkah strategi PDEODE yang ditetapkan. Bentuk dari lembar observasi ini adalah checklist $(\checkmark)$ artinya observer akan memberikan tanda checklist $(\checkmark)$ jika kriteria yang dimaksud dalam format observasi terlaksana. Tes skala sikap siswa atau angket untuk siswa berupa daftar isian yang harus diisi oleh siswa dengan tujuan mengetahui tanggapan siswa mengenai strategi pembelajaran
PDEODE yang terdiri dari dua pilihan yaitu setuju dan tidak setuju. Instrumen skala siswa ini juga menggunakan checklist $(\checkmark)$ artinya siswa hanya memberikan tanda $\checkmark$ jika sesuai dengan yang mereka rasakan. Data yang diperoleh dalam penelitian ini merupakan data kuantitatif yang diperoleh melalui tes tertulis dan hasil observasi keterlaksanaan model pembelajaran.

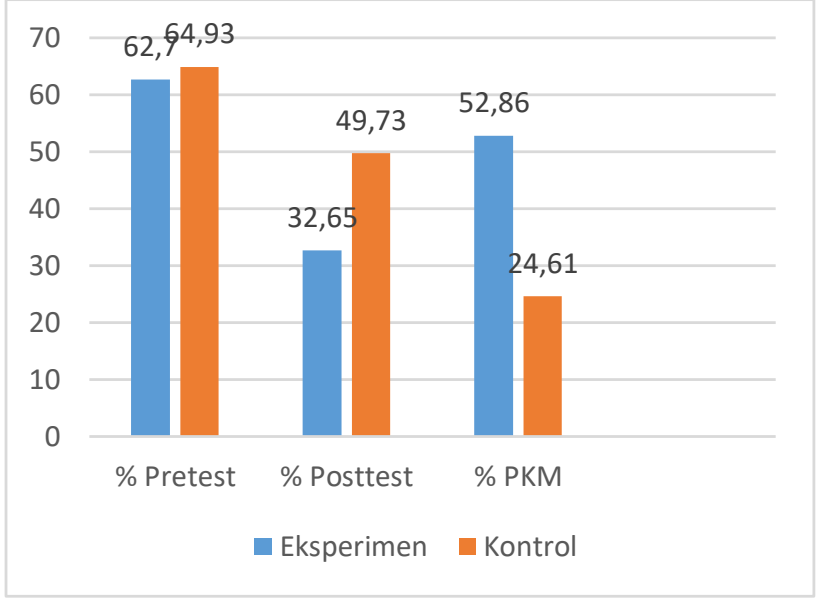

Gambar 1 Presentase PKM Siswa Kelas Eksperimen dan Kelas Kontrol

\section{HASIL DAN PEMBAHASAN}

Hasil keterlaksanaan proses pembelajaran dan aktivitas siswa pada kelas eksperimen di atas $75 \%$ dengan kriteria hampir seluruh kegiatannya terlaksana. Dalam penelitian ini siswa yang mengalami miskonsepsi, paham konsep, kurang paham konsep, menebak dan tidak paham konsep dapat diidentifikasi menggunakan Three Tier Test (TTT). TTT terdiri dari tiga tingkat soal, soal tingkat pertama (first tier) merupakan pertanyaan pilihan ganda dan soal tingkat kedua (second tier) merupakan alasan dari pemilihan jawaban first tier. Soal tingkat ketiga (third tier) berupa pilihan tingkat keyakinan siswa dalam memilih jawaban first tier dan second tier. Data yang diperoleh dari hasil pretest dan posttest siswa kemudian di analisis setiap butirnya. Berdasarkan data yang diperoleh, presentase jumlah siswa pada kelas eksperimen yang mengalami 
miskonsepsi saat pretest dan posttest mengalami penurunan. Penurunan jumlah siswa yang mengalami miskonsepsi terjadi pada seluruh konsep perubahan wujud benda. Hal ini menunjukkan treatment yang dilakukan pada kelas eksperimen dapat meningkatkan pemahaman konsep siswa dari yang tidak tahu konsep, kurang paham konsep, menebak maupun yang miskonsepsi menjadi paham konsep.

Penurunan jumlah siswa yang mengalami miskonsepsi terjadi pada seluruh konsep perubahan wujud benda. Penurunan yang terjadi lebih besar di kelas eksperimen hal ini menunjukkan bahwa treatment yang dilakukan pada kelas eksperimen dapat lebih meningkatkan pemahaman konsep siswa dari yang tidak tahu menjadi tahu.

Perbandingan presentase rata-rata miskonsepsi pretest, posttest, dan penurunan kuantitas miskonsepsi siswa antara kelas eksperimen dan kontrol disajikan pada gambar berikut :

Hasil pretest di kelas eksperimen banyak siswa yang mengalami miskonsepsi sebanyak $62.7 \%$ dan hasil posttest menunjukkan terjadi penurunan yang cukup siginifikan menjadi $32.65 \%$ siswa yang mengalami miskonsepsi, presentasi penurunan kuantitas miskonsepsi untuk kelas eksperimen yang menggunakan strategi pembelajaran PDEODE adalah sebanyak $52.86 \%$. hasil tersebut cukup signifikan disbanding kelas kontrol yang mengalami penurunan hanya $24.61 \%$.

Dari kegiatan yang telah dilaksanakan, diperoleh data skor pretest dan posttest untuk mengetahui peningkatan pemahaman konsep siswa pada materi perubahan wujud benda. Berdasarkan data hasil pretest dan posttest diperoleh ratarata skor pretest untuk kelas eksperimen awalnya 17,83 meningkat menjadi 23,57 pada saat posttest dengan gain yang di normalisasi sebesar 0.361 kategori sedang. Sedangkan untuk kelas kontrol rata-rata skor pretest awalnya 18,03 meningkat menjadi 20,73 pada saat posttest dengan gain yang di normalisasi sebesar 0.172 berkategori rendah. Ratarata $\mathrm{N}$-gain kelas eksperimen termasuk ke dalam kategori sedang dan kelas kontrol termasuk dalam kategori rendah dan $\mathrm{N}$ Gain pemahaman konsep yang paling tinggi terdapat pada kelas eksperimen. Hal ini menunjukkan bahwa peningkatan pemahaman konsep siswa kelas eksperimen lebih tinggi dari pada kelas kontrol pada konsep perubahan wujud benda.

Selanjutnya diagram berikut menyajikan perbedaan N-gain antara kelas eksperimen dan kelas kontrol pada gambar berikut:

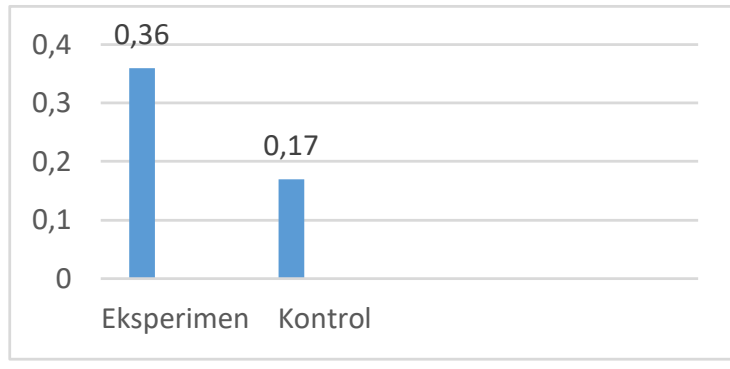

Gambar 2. Perbedaan N-Gain

Pada gambar 2 diatas menunjukkan bahwa perhitungan $\mathrm{N}$-gain berdasarkan hasil pretest dan posttest kelas eksperimen dan kelas kontrol terdapat perbedaan yang cukup signifikan di antara keduanya. Gain untuk kelas eksperimen 0.36 dan untuk kelas kontrol 0.17. Selanjutnya untuk mengetahui signifikansi perbedaan peningkatan pemahaman konsep pada konsep perubahan wujud benda kelas eksperimen dan kelas kontrol, maka dilakukan uji statitstik terhadap hipotesis yang telah diajukan. Tahap pertama pengujian ini adalah uji normalitas data terhadap $N$-Gain untuk semua siswa pada kelas eksperimen dan kelas kontrol.

Selanjutnya dilakukan uji hipotesis dengan menggunakan statistik parametrik (uji-t). Hal ini dilakukan karena data kedua kelompok berdistribusi normal dan memiliki varians yang sama (homogen). 
Uji ini dimaksudkan untuk memastikan apakah hipotesis yang diajukan dapat diterima atau ditolak. Berdasarkan hasil perhitungan, hasil uji t satu ekor untuk pembelajaran kedua kelas dapat dilihat pada tabel 1.1 berikut :

\section{Tabel 1. Hasil Uji-t}

Data Peningkatan Pemahaman Konsep

\begin{tabular}{|c|c|c|}
\hline $\boldsymbol{T}_{\text {hitung }}$ & $\boldsymbol{t}_{\text {tabel }}$ & Kesimpulan \\
\hline 4.01 & 2.00 & Ha diterima \\
\hline
\end{tabular}

Berdasarkan data pada tabel diatas, terlihat bahwa hasil uji hipotesis dengan uji satu ekor adalah $t_{\text {hitung }}>t_{\text {tabel }}$, artinya skor rata-rata $\mathrm{N}$-gain kelas eksperimen lebih tinggi dari skor rata-rata kelas kontrol. Hal ini menunjukkan bahwa $\mathrm{H}_{\mathrm{o}}$ berada di daerah penolakan artinya $\mathrm{H}_{\mathrm{o}}$ ditolak dengan demikan diperoleh kesimpulan bahwa terjadi peningkatan pemahaman konsep siswa yang memperoleh pembelajaran dengan strategi PDEODE yang signifikan dibandingkan peningkatan pemahaman konsep siswa yang mendapatkan pembelajaran tradisional. Berdasarkan hal tersebut maka hasil uji-t dapat dilihat pada Gambar 3.
PDEODE ini sedangkan $16 \%$ siswa merasa bahwa pembelajaran PDEODE ini tidak ada bedanya dengan pembelajaran sebelumnya, hal ini bisa disebabkan beberapa siswa tersebut kurang konsentrasi dan kurang menyimak pada saat kegiatan belajar berlangsung. Sebanyak $87 \%$ siswa mengalami peningkatan pada aspek menjelaskan dan 84\% siswa mampu menginferensi dan membandingkan konsep-konsep yang dipelajari dan sisanya dengan rata-rata $15 \%$ siswa belum mengalami peningkatan tersebut.

Selanjutnya hampir $84,75 \%$ siswa merasa tertarik dengan pembelajaran PDEODE sisanya sebanyak $15.25 \%$ merasa kurang tertarik dengan pembelajaran PDEODE, dan 90\% siswa merasa dilibatkan secara penuh dalam kegiatan belajarnya sedangkan sisanya $10 \%$ siswa merasa tidak ikut terlibat dalam kegiatannya. Hal ini bisa jadi disebabkan karena masih adanya sebagian siswa yang mendominasi dan kurang memberikan kesempatan pada siswa lainnya untuk ikut berpartisipasi dalam

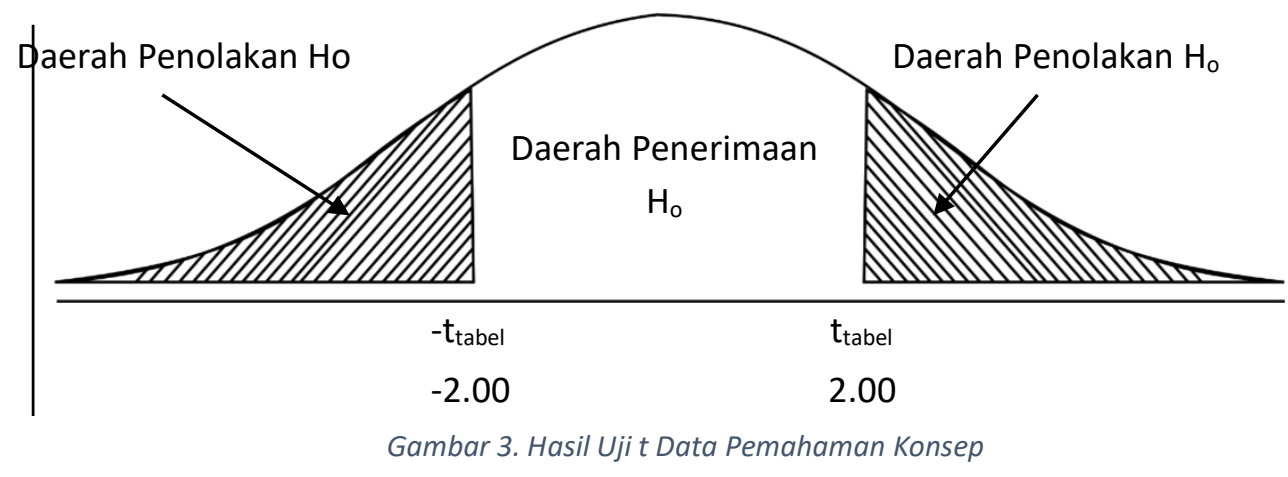

Untuk mengetahui skala sikap siswa terhadap pembelajaran PDEODE pada materi perubahan wujud benda, dilakukan dengan membagikan lembar skala sikap kepada siswa. Pengisian lembar skala sikap dilakukan setelah seluruh pembelajaran dilaksanakan dengan jumlah responden 30 siswa. Hasil yang diperoleh menunjukkan bahwa sebanyak $84 \%$ siswa menganggap bahwa baru pertama kali mendapatkan pengalaman belajar dengan percobaan seperti kegiatannya.

Masalah yang ditemui dalam proses pembelajaran adalah kesulitan menganalisis dan kesulitan memprediksi, sebanyak $75 \%$ siswa mengalami kesulian memprediksi jawaban dan sebanyak $78 \%$ mengalami kesulitan menganalisis jawaban setelah dilakukan kegiatan observasi. Namun, penurunan kuantitas siswa yang miskonsepsi cukup signifikan yakni sebanyak $84 \%$ siswa mengalami penurunan. 


\section{KESIMPULAN}

Berdasarkan hasil temuan, hasil pengolahan dan analisis data terhadap data hasil penelitian yang telah dilakukan, diperoleh kesimpulan bahwa :

1. Pembelajaran di kelas yang menggunakan strategi PredictDiscuss-Explain-Observe-Discuss-

Explain (PDEODE) mengalami peningkatan dalam pemahaman konsep dengan gain rata-rata 0.36 sedangkan pembelajaran di kelas yang menggunakan pembelajaran tradisional meskipun mengalami peningkatan namun tidak terlalu signifikan dengan gain rata-rata 0.17.

2. Pembelajaran yang menggunakan PDEODE juga mengalami penurunan kuantitas siswa yang miskonsepsi dengan persentase siswa sebanyak $52.86 \%$ siswa yang mengalami penurunan miskonsepsi, sedangkan kelas yang menggunakan pembelajaran tradisional meskipun mengalami penurunan kuantitas miskonsespsi juga namun tidak cukup signifikan hanya sekitar $24.61 \%$ siswa saja.

\section{SARAN}

Penelitian yang telah dilaksanakan masih jauh dari penelitian sempurna. Berdasarkan hasil penelitian yang telah dilaksanakan, peneliti mengajukan beberapa rekomendasi kepada pihakpihak terkait dalam kegiatan pembelajaran di lembaga pendidikan sebagai berikut :

1. Strategi pembelajaran PDEODE merupakan kegiatan belajar yang memusatkan kegiatannya pada siswa, maka guru harus melakukan pengawasan secara lebih intensif lagi kepada setiap kelompokkelompok siswa sehingga kesulitan siswa dalam mengambil data dapat diatasi bersama antara guru dan murid.
2. Hasil tanggapan siswa menunjukkan kesulitan terbanyak dalam kegiatan belajara dengan stategi PDEODE ini adalah dalam hal prediksi dan menganalisis, maka guru perlu membimbing terutama dalam 2 kegiatan tersebut prediksi dan analisis hasil prediksi karena ternyata banyak siswa yang kesulitan dalam menjelaskan antara hasil eksperimen dengan hasil observasi.

3. Berdasarkan hasil belajar di kelas dengan jumlah siswa yang cukup banyak maka kemampuan guru dalam manajemen kelas harus lebih dioptimalkan lagi.

4. Guru harus mampu memilih pertanyaan apersepsi sebelum kegiatan pembelajaran agar dapat mengarahkan siswa untuk berpikir kritis sehingga siswa terbantu untuk mengubah konsepnya yang salah pada saat kegiatan belajar berlangsung.

\section{DAFTAR PUSTAKA}

Carin, A. \& Sund, R. (1989). Teaching science through discovery ( $6^{\text {rd }}$ edition). Merril Publishing Company: Columbus, Ohio.

Clara, dkk. (2013). Miskonsepsi siswa kelas rangkap SDN 47 sekadau pada materi sifat \& perubahan wujud benda. Jurnal Pendidikan dan Pembelajaran Universitas Tanjungpura Pontianak Vol 2, No 10.

Costu, B., et.all. (2008). Learning science through the PDEODE teaching strategy: helping students make sense of everyday situations. Eurasia Journal of Mathematics, Science \& Technology Education, Vol 4(1) no 3-9.

Kambouri, M. (2012). Children's misconceptions and a look on how teachers respond to them. Paper. London: University of Reading. 
Palmer, D. (1996). Assesing students using the "POE". Australian Primary \& Junior Science Journal Vol 12 No 3.

Sigit, A. \& Nurmala. (2011). Pemahaman siswa SD terhadap konsep IPA berbasis kimia. Universitas Terbuka. Diakses dari: http://lppm.ut.ac.id/htmpublikasi/42 arganur.htm. 7 Januari 2015.

Wulandari, T. S. H. (2013). Penerapan strategi PDEODE dalam mengatasi miskonsepsi dan meningkatkan keterampilan berpikir kritis pada botani tumbuhan rendah. Diakses dari:

http://id.portalgaruda.org/index.php ?ref=browse \& mod=viewarticle\&art icle $=139061$. Prosiding Seminar Nasional X Pendidikan Biologi Universitas Sebelas Maret Vol 10, No 1. 15 Januari 2016 